\title{
Human $\mathrm{CC} 10$, the homologue of rabbit uteroglobin: genomic cloning, chromosomal localization and expression in endometrial cell lines
}

\author{
Markus Wolf, Jörg Klug, Reinhard Hackenberg ${ }^{1}$, Manfred Gessler², Karl-Heinz Grzeschik², \\ Miguel Beato and Guntram Suske* \\ Institut für Molekularbiologie und Tumorforschung. Philipps-Universităt Marburg, Emil-Mannkopff-Straße 2, \\ W-3550 Marburg. 'Marburger Frauenklink, Pilgrimstein 3, W-3550 Marburg and ${ }^{2}$ Institut für Humangenetik, \\ Bahnhofstraße 7a, W-3550 Marburg, Germany
}

\begin{abstract}
Human and rat cDNAs to Clara Cell $10 \mathrm{kDa}$ protein (CC10) have been previously isolated. Comparison of the amino acid sequences showed that $\mathrm{CC10}$ is homologous to rabbit uteroglobin. Here we present further evidence that human CC10 is the human counterpart of rabbit uteroglobin. We have isolated the gene and have mapped its genomic Jocalization to chromosome 11q11-qter. Sequence analysis of the 5 -nanking region reveals that the homology between the human and the rabbit gene starts at the first exon/intron boundary and extends up to $-1.4 \mathrm{~kb}$. A second region of 0.74 $\mathrm{kb}$ from -1.77 to $-2.51 \mathrm{~kb}$ in the human 5 -flanking gene region is homologous to rabbit sequences that include four progesterone receptor binding sites which have been implicated in progesterone regulation of rabbit uteroglobin gene expression in endometrium. Sequence alignment of this region on the nucleotide level shows that only two weak progesterone receptor binding sites are partially conserved. In addition, close inspection of the human and rabbit promoters reveals that the estrogen responsive element and two recently identified cis elements of the rabbit promoter located between -177 and -258 bp are also absent in the human uteroglobin promoter. Despite these differences in the 5 '-flanking regions of the genes, we report that the human uteroglobin mRNA is expressed in a human cell line of endometrial origin indicating that human uteroglobin is expressed in the uterus like its rabbit homologue. Thus, it appears that human uteroglobin is not only a marker for lung Clara cells but also an endometrial differentiation marker. Human uteroglobin cDNA or antibodies to the protein may be used to characterize endometrium derived tumors.
\end{abstract}

\section{INTRODUCTION}

Clara cell $10 \mathrm{kDa}$ secretory protein (CCl0), also called Clara cell $17 \mathrm{kDa}$ protein, is a homodimer consisting of $8.5 \mathrm{kDa}$ monomers that are joined by two disulfide bonds (1). It is the predominant secreted protein of lung Clara cells which are lining the bronchiolar epithelium $(2,3)$. The physiological role of the protein is not yet completely understood. It has been reported that $\mathrm{CClO}$ specifically binds methylsulfonyl-polychlorated biphenyls (4) and inhibits phospholipase $A_{2}(5)$. In the last few years the sequences of rat $(6,7)$ and human (8) CC10 cDNAs have been reported. These cDNAs and the derived amino acid sequences show striking homologies to rabbit uteroglobin $(5,7)$. Nevertheless, it has been doubted that $\mathrm{CC10}$ is uteroglobin (5).

Like $\mathrm{CCl} 0$ rabbit uteroglobin is a covalently bound homodimer whose three-dimensional structure is well known (9). Uteroglobin expression in rabbits has been originally reported in the uterus during the preimplantation phase (10). More recently, the protein was also detected in oviduct (11), male genital organs (12), esophagus (13) and lung $(13,14)$. In vitro, several distinct properties of uteroglobin have been described. Soon after its discovery it could be shown that the steroid hormone progesterone is specifically bound by the protein $(15,16)$. Therefore, rabbit uteroglobin was believed to be a potential carrier or scavenger of progesterone that regulates the progesterone concentration in the endometrium (17). It has also been shown to specifically bind certain methylsulfonyl-metabolites of polychlorinated biphenyls (PCBs) with even higher affinity than progesterone (18). These xenobiotic PCB metabolites accumulate in the same lung cells that secrete uteroglobin (19). Furthermore uteroglobin has been found to inhibit phospholipase $A_{2}(20,21,22)$. The relationships of all these properties and their physiological significance is still not understood and remains largely a matter of speculation.

Expression of rabbit uteroglobin in the various tissues is regulated differentially by different steroid hormones. In the endometrium, progesterone and to a lesser extent estradiol increase transcription of the gene $(23,24)$, whereas in epididymis and lung, testosterone and cortisol, respectively, are the active hormones that enhance expression $(25,26,27)$. Moreover, closer examination of the expressing tissues revealed that expression is restricted to certain epithelial cells. For instance, in uterus only the glandular and luminal epithelium express uteroglobin (28). In lung, expression of the protein is restricted to Clara cells.

Genomic clones encoding rabbit uteroglobin have been isolated $(29,30)$ and regions $5^{\prime}$ to the gene identified that are probably responsible for its hormonal regulation $(31,32,33)$. Binding sites for purified glucocorticoid and progesterone receptors are located at positions around $-2.7 \mathrm{~kb}$ and $-2.4 \mathrm{~kb}$ (32). An estrogen responsive element is present at $-0.25 \mathrm{~kb}$ (33). These steroid

- To whom correspondence should be addressed 
hormone receptor binding sites correlate with DNasel hypersensitive regions found exclusively in chromatin from endometrium of hormonally stimulated rabbits (32).

Uteroglobin had been found only in rabbits and two other members of the order Lagomorpha, namely hare and pica (34). Most antisera to rabbit uteroglobin do not cross-react with proteins of other species and the rabbit uteroglobin CDNA does not cross-hybridize to DNA/RNA from other species (our unpublished data). Recently, we showed that the rat CC10 mRNA is expressed like rabbit uteroglobin not only in lung but also in the esophagus as well as in uteri of estrogen and progesterone treated female rats (7) suggesting that rat $\mathrm{CClO}$ is the rat counterpart of rabbit uteroglobin. In addition, mouse $\mathrm{CC} 10$ is expressed in the same cell types like the rabbit uteroglobin in transgenic mice (35).

In this paper we present by evolutionary considerations further evidence that human $\mathrm{CC} 10$ is the human counterpart of rabbit uteroglobin. We report the cloning of the gene and mapping of its chromosomal locus. In addition, we present the nucleotide sequence of the 5'-regulatory region and compare it to the corresponding rabbit and rat sequences. Furthermore, we show that human CC10 mRNA is not only expressed in lung Clara cells but also in an epithelial cell line of endometrial origin.

\section{RESULTS}

Comparison of human and rat $\mathrm{CClO}$ to rabbit and hare uteroglobin cDNAs

Previously a human cDNA clone encoding $\mathrm{CCl} 10$ was isolated from a human lung cDNA library (8). Alignment of this CDNA clone to the rabbit uteroglobin (29), hare uteroglobin (36) and rat $(6,7) \mathrm{CC} 10 \mathrm{cDNAs}$ reveals overall identities in the coding region of $75 \%, 77 \%$ and $67 \%$, respectively (Fig. 1). In addition, the open reading frames of the human, rabbit and hare clones have the same length of 273 bp encoding 91 amino acids. The open reading frame of the rat $\mathrm{cDNA}$ is $288 \mathrm{bp}$ in length, due to a 15 bp extension at the $3^{\prime}$ end of the coding region. Although there is no cross-hybridization between the rabbit uteroglobin and human CC10 cDNA clones, probably due to the absence of a longer nucleotide stretch with $100 \%$ identity, the sequence identities strongly suggest that the human $\mathrm{CC} 10 \mathrm{cDNA}$ encodes the human homologue of rabbit and hare uteroglobin. This idea is further supported by side-by-side comparison of the amino acid sequences (5) and evolutionary considerations.

In the coding regions of $\mathrm{CClO}$ /uteroglobin the average number of substitutions per nonsynonymous and synonymous site between man and rabbit are lower than between rat and man or rat and rabbit (Table 1). A similar situation is observed for other genes (for comparison see values for the apolipoprotein E gene (37) and average values for 14 other genes (38) in Table 1). Thus, the rabbit and human uteroglobin genes are more closely related to each other than to the rat gene. This finding is in agreement with previous data showing that the divergence of lagomorphs from the main mammalian lineage occured after the divergence of rodents $(38,39)$. If human/rat $\mathrm{CC10}$ and rabbit uteroglobin were two different genes, this would imply that all three species must have a $\mathrm{CC} 10$ and a uteroglobin gene, whereby the $\mathrm{CC} 10$ genes must be more closely related to each other than to the uteroglobins and vice versa. Since this is not the case these data provide good evidence that rat and human $\mathrm{CClO}$ and uteroglobin are the same gene.

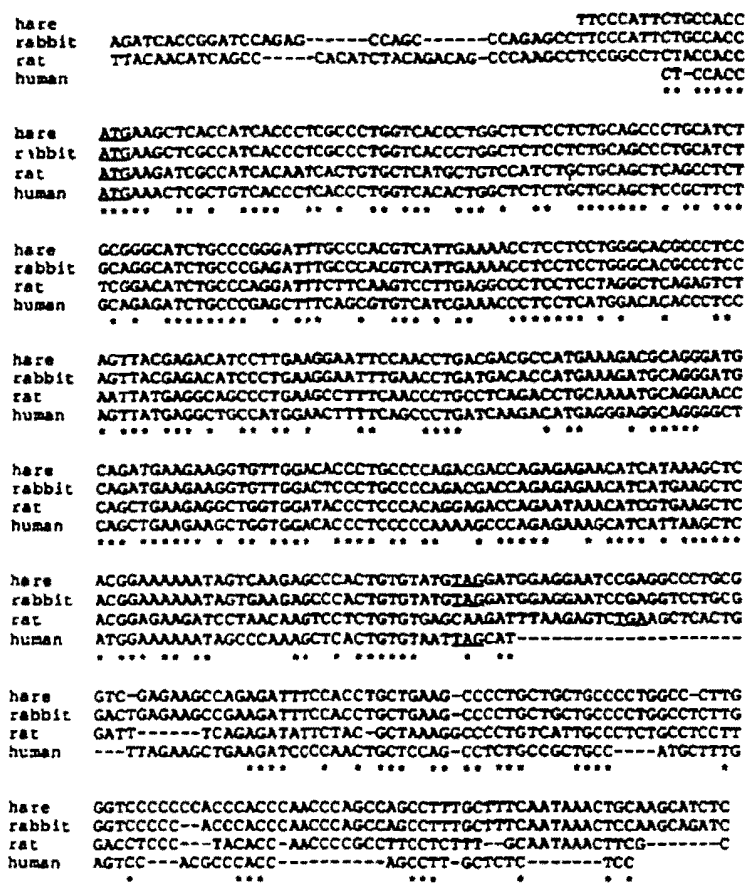

Figure 1. Alignment of hare and rabbit uteroglobin and rat and human CC10 cDNAs using the CLUSTAL program (58). The start (ATG) and the stop codons (TAG in hare, rabbit and human and TGA in rat) are underlined. Nucleotides that are identical in all four cDNA sequences are marked by asterisks. Broken lines in the $5^{\prime}$ - and $3^{\prime}$-untranslated regions indicate gaps permitung best alignment.

Table 1. Average number of substitutions between genes from man, rabbit and rat. The coding regions of uteroglobin/CCIO (UG) and apolipoprotein E (Apo E) CDNAs were aligned and the number of substitutions per synonymous (above diagonal) and nonsynonymous site (below diagonal) calculated according to $\mathrm{Li}$ et al. (57) using the LWL90 program written by K.H. Wolfe (unpublished). For further comparison, the average number of substitutions for 14 genes taken from (38) are presented.

\begin{tabular}{|c|c|c|c|c|}
\hline & & Man & Rabbit & Rat \\
\hline Man & $\begin{array}{c}\text { UG } \\
\text { Apo } \mathrm{E} \\
\text { Average }\end{array}$ & & $\begin{array}{l}0.507 \\
0.179 \\
0.414\end{array}$ & $\begin{array}{l}0.828 \\
0.315 \\
0.577\end{array}$ \\
\hline Rabbit & $\begin{array}{c}\text { UG } \\
\text { Apo E } \\
\text { Average }\end{array}$ & $\begin{array}{l}0.250 \\
0.147 \\
0.062\end{array}$ & & $\begin{array}{l}0.811 \\
0.338 \\
0.612\end{array}$ \\
\hline Rat & $\begin{array}{c}\text { UG } \\
\text { Apo } \mathrm{E} \\
\text { Average }\end{array}$ & $\begin{array}{l}0.294 \\
0.213 \\
0.082\end{array}$ & $\begin{array}{l}0.323 \\
0.248 \\
0.085\end{array}$ & \\
\hline
\end{tabular}

\section{Isolation of the human $\mathrm{CC10}$ gene}

Previously it was shown that the human $\mathrm{CCl} 10$ gene is a single copy gene ((8) and own unpublished results) as found for the rat and rabbit genes $(7,29)$. In order to isolate the potential regulatory 5 '-flanking region of the gene we have screened approximately 500,000 independent plaques of a human genomic lambda phage library using the human $\mathrm{CC} 10 \mathrm{cDNA}$ as probe. A single recombinant phage was isolated and partially analyzed 
by restriction enzyme mapping and Southem bloting. The insert includes approximately $20 \mathrm{~kb}$ of human genomic DNA. To identify and subclone a fragment that contains the 5 -flanking region of the human $\mathrm{CC} 10$ gene we hybridized restricted phage DNA separately with $5^{\prime}$ and $3^{\prime}$ parts of the cDNA. A 60 bp Eco RI-Pst I fragment from the human CDNA clone containing the codons for the 16 most $\mathrm{NH}_{2}$-terminal amino acids hybridizes exclusively to a $4.4 \mathrm{~kb}$ Bam HI-Hind III fragment of the recombinant phage DNA. The remaining 3'-part ( $300 \mathrm{bp})$ of the human CDNA gives no signal with this DNA fragment. These results indicated that the fragment contains probably the first exon and 5 '-flanking sequences. For sequencing, the Bam HI-Hind III fragment was subcloned into the polylinker site of the plasmid pSPT 19. A partial restriction map of the subcloned Bam HI-Hind III fragment is shown in Fig. 2A. The $5^{\prime}$ end of the first exon has been determined by SI nuclease mapping with RNA from human lung. RNA from a cell line that does not express human $\mathrm{CC} 10$ was used as negative control. A 283 bp Pst I-Sac I fragment (see Fig. 2A) overlapping the presumed transcription start site was used as hybridization probe. The autoradiogram of Fig. 2B shows two major bands separated by two nucleotides located about 60 nucleotides upstream of the translation start point. This result suggests two different transcriptional start points separated by two nucleotides. For the assignment of these two start points to the $\mathrm{A}^{\prime}$ 's at the indicated positions in Fig. $2 \mathrm{~B}$ we took into account the different electrophoretic mobility of fragments generated by $\$ 1$ nuclease and by the corresponding sequencing ladder (40). We arbitrarily assigned the proximal transcriptional start point as +1 . A typical TATA motif is found thirty nucleotides further upstream. The 3' end of the first exon could be defined by the divergence of the cDNA and genomic sequences. The deduced exon/intron boundary is in agreement with the consensus donor splice site found in many other eucaryotic genes. In addition, this exon/intron boundary is found exactly at the same position in the rabbit uteroglobin and rat $\mathrm{CClO}$ genes $(7,30)$. Alignment of the human $\mathrm{CC10}$ gene 5 -flanking sequence with itself using the dot matrix program of the Sequence Analysis Software Package from the Genetics Computer Group of Wisconsin (UWGCG) (4I) identifies three regions that show considerable homology to each other (data not shown). These sequences are located around $-3,000,-2,600$ and $-1,500 \mathrm{bp}$. A computer search for homologies to sequences stored in the EMBL database identifies these sequences as Alu repetetive sequences $(42,43)$.

The 5'-flanking region of the human $\mathrm{CC10}$ gene is partially homologous to the rat $\mathrm{CC10}$ and rabbit uteroglobin gene

Comparison of the $3.35 \mathrm{~kb} 5^{\prime}$-flanking sequence of the human CCl0 gene with the known 5 -flanking sequences of the rabbit and rat homologues reveals two regions with considerable homology (Fig. 3). The homology to the rabbit gene starts at the first exon/intron boundary and extends up to the first Alu repeat at around $-1,420 \mathrm{bp}$. It appears that the absence of homologous rabbit sequences in the human gene between $-1,420$ and $-1,770 \mathrm{bp}$ is mainly due to the substitution by an Alu repeat. The second homologous region lies between the first and second Alu repetetive sequence between $-1,770$ and $-2,510$ bp relative to the transcription start point. This region is homologous to a sequence between $-2,659$ and $-2,333$ bp of the rabbit uteroglobin gene (32) which is absent in the rat gene ( 7 ). Interestingly, in the rabbit gene this region includes four progesterone receptor binding sites that have been implicated in

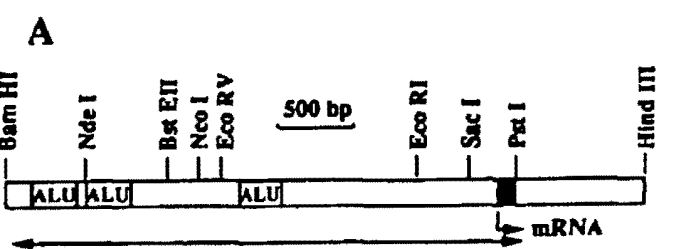

B

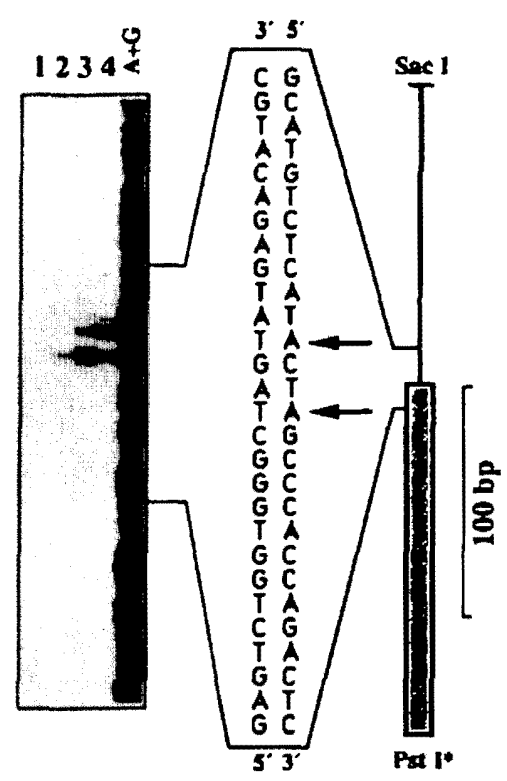

Figure 2. Structure of the human $\mathrm{CClO}$ gene S'-flanking region. A, Partial restriction map of the Bam HI-Hind III fragment obtaned from the recombinant phage containing human $\mathrm{CCl} 0$ coding sequences. The transcriptional start point is indicated by an arrow (mRNA). The shaded region denotes the first exon. The positions of the Alu sequences are marked (Alu). The double-headed arrow indicates the sequenced region. B, SI nuclease mapping. The diagram on the right depicts the Pst I-Sac I restriction fragment around the first exon (shaded region). On the left. the autoradiogram of a $6 \%$ sequencing gel is shown. The 5. 32P-labelled fragment was hybridized to $10 \mu \mathrm{g}$ total RNA from a nonexpressing cell line (lane I) and lung (lanes 2-4), respectively. S1 nuclease digestion was performed under the following conditions. Lanes 1 and 3,400 U SI nuclease, lane 2, 900 U SI nuclease and lane 4, $150 \mathrm{U}$ SI nuclease. Lane $A+G$, sequencing ladder. The arrows indicate the transcriptional start pounts.

progesterone regulation of uteroglobin gene expression in the endometrium of rabbits during early pregnancy (32). In addition, two DNase I hypersensitive sites lie in that region of the rabbit gene (32). Sequence alignment of this region on the nucleotide level reveals that the two strong progesterone receptor binding sites (A and D in Fig. $4 \mathrm{~A}$ ) are not conserved in the human gene. The two weak binding sites of the rabbit gene (B and $C$ in Fig. 4 A) are partially conserved in the corresponding human 5 '-flanking region. In addition, despite the obvious homology of the proximal promoter region, an estrogen responsive element found at -263 to -251 bp upstream of the rabbit uteroglobin gene (33) is completely absent in the human gene (Fig. 4B). The finding that the estrogen responsive element described for the rabbit gene is not conserved in the human gene resembles the situation in the rat $\mathrm{CClO}$ gene region where this element is also absent (7).

Very recently we have identified cis-elements in the promoter 


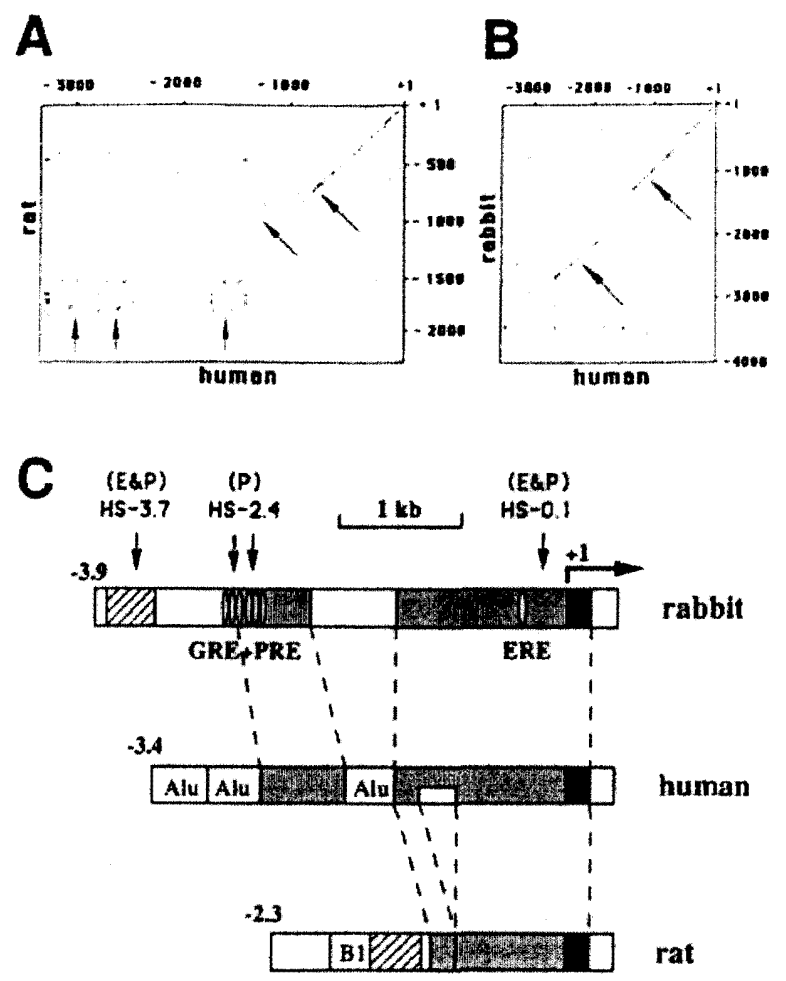

Figure 3. Similarities of the human $\mathrm{CClO}$, rabbit uteroglobin and rat $\mathrm{CC} 10$ 5'-flanking gene regions. A and B. The sequences were compared by a do matrix program. In the matrix, each dof represents 14 identities per 21 nucleotides. Regions of homology are indicated by slanted arrows. The vertical arrows depict the Alu repetetive sequences that show some similarity to the rat Bl sequence. The human $\mathrm{CC} 10$ gene region from $-3,349$ to +1 bp is compared with the ral gene region from $-2,320$ to $+1 \mathrm{bp}(\mathrm{A})$ and the rabbit uteroglobin region from $-3,995$ to +1 (B). C, Schematic drawing of the human CC10, rabbit uteroglobin and rat $\mathrm{CC} 105^{\prime}$-flanking gene regions. Hatched and shaded boxes show regions of greater than $66 \%$ overall homology. In the rabbit uteroglobin gene binding sites for glucocorticoid (GRE), progesterone (PRE) and estrogen receptor (ERE) are marked. DNasel hypersensitive sites (HS) found in chromatin of estrogen (E) and progesterone (P) stimulated rabbit endometrium are indicated by arrows.

region of the rabbit uteroglobin gene between $-400 \mathrm{bp}$ and the transcription start point that mediate preferential transcription of a reporter gene in the endometrial cell line Ishikawa (44). One of these regions $(-258 /-220)$ includes a motif that is in 12 out of 13 nucleotides identical to the GT-I motif in the SV40 enhancer. This GT-I motif includes a CACCC element. Although the GT-I motif is absent in the human promoter, a CACCC motif is found between -202 and $-198 \mathrm{bp}$ (Fig. 4B) that is conserved at the corresponding position in the rat gene (7). Two other relevant cis-elements of the rabbit uteroglobin promoter, the so called uteroglobin upstream elements (UE) that are in 12 out of 13 nucleotides identical (see Fig. 4B) and bind probably the same transcription factor (44) are also not well conserved in the human promoter. In contrast, a 7 bp perfect inverted repeal (CAGTTTC) that is also found in the long terminal repeat (LTR) of all murine leukemia viruses and provinuses and therefore designated 'LTR $\mathrm{Pal}$ ' is conserved between the rabbit und human promoter (Fig. 4B). In addition, two identical A/T rich sequence motifs that are similar to the octamer motif found in many eucaryotic

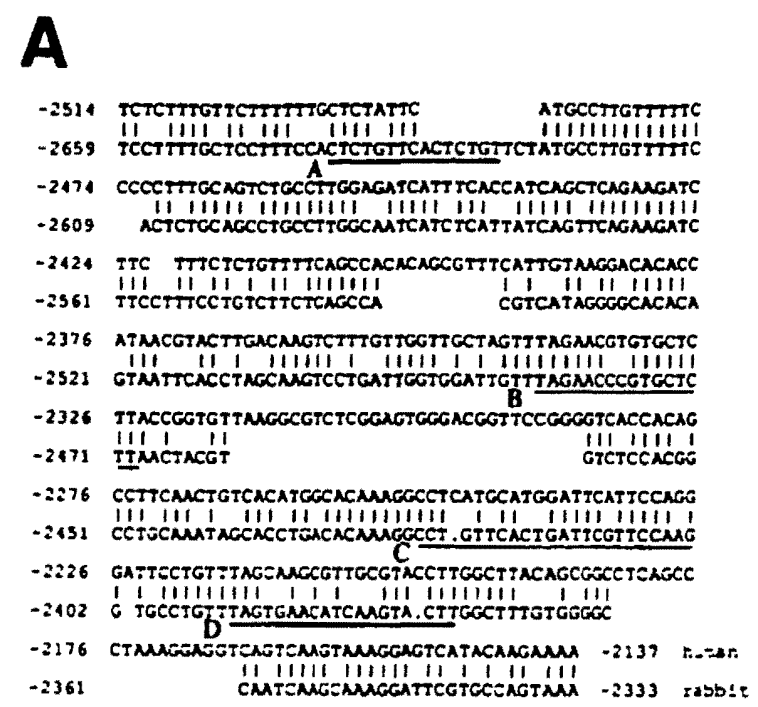

B

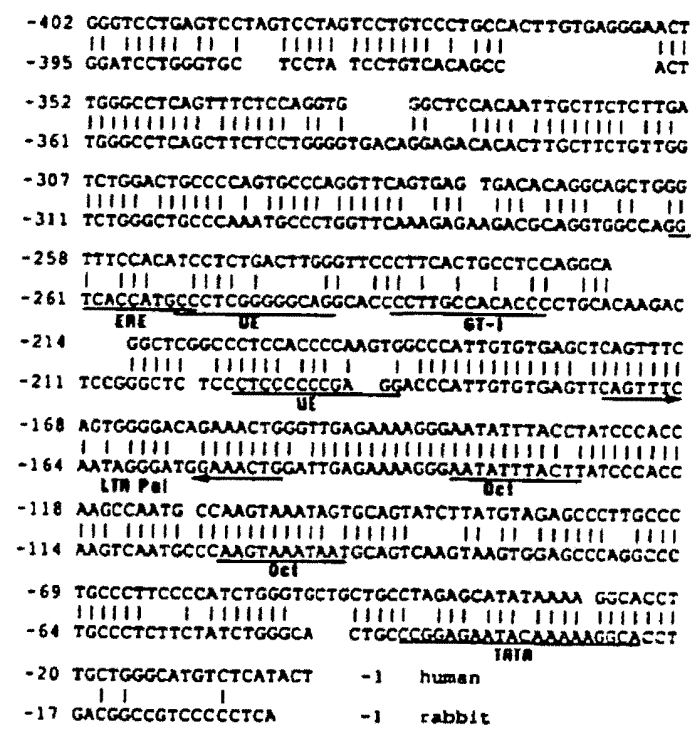

Figure 4. Sequence alignments of homologous humen $\mathrm{CC} 10$ and rabbit uteroglobin 5 -flanking gene sequences using the GCG program 'Best Fit'. A, The human CCl0 gene sequence (upper sequence) from $-2,514$ to $-2,137$ bp is aligned to the rabbit uteroglobin S'-flanking gene sequence (lower sequence) from $-2,659$ to $-2,333 \mathrm{bp}$. In the rabbit gene, the two strong ( $A$ and $D$ ) and the two weak (B and C) progesterone receptor binding sites according to Jantzen et al. (32) are underlined. B. The promoter region of the rabbit uteroglobin gene (lower sequence) from -395 to -1 bp is aligned to the corresponding human $\mathrm{CClO}$ gene region (upper sequence). Recently identified cis-elements of the rabbit promoter $(33,44)$ are underlined and designated ERE (estrogen responsive element). GT-I (GT-I motif found in the SV40 entancer). LTR Pal (palindromic sequence found in the long terminal repeat of munne leukemia viruses), Oct (sequence motifs that bund purified Oct-1 specifically) and the TATA region (TATA box).

promoters (45) and do bind purified Octl specifically (unpublished results) are conserved in the human promoter around $-100 \mathrm{bp}$ and $-135 \mathrm{bp}$. Most interestingly, in DNasel footprinting experiments a protection over the rabbit uteroglobin TATA-box 


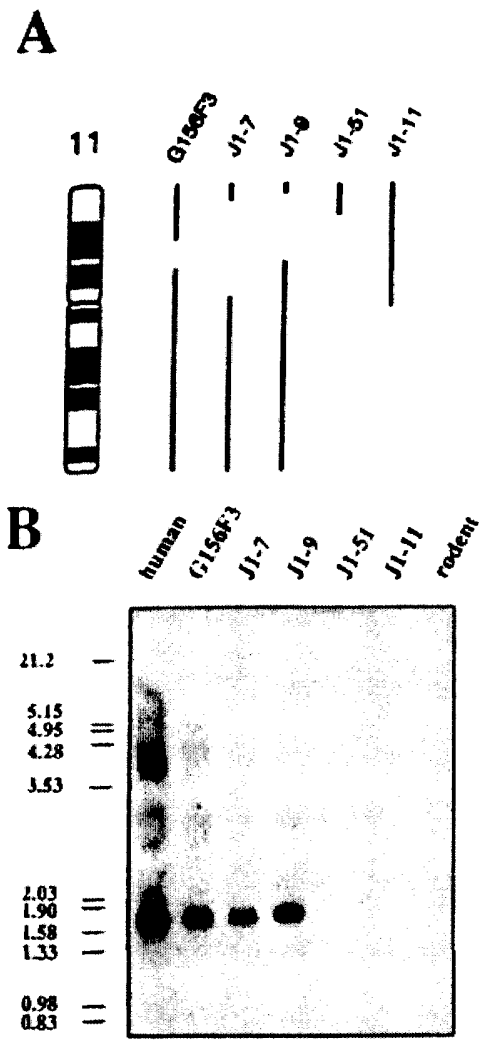

Figure 5. Subregional chromosomal mapping of the human $\mathrm{CClO}$ gene. A, Schematic drawing of human chromosome 11 (left) and remaining chromosome 11 fragments (indicated by vertical lines) in various somatic cell hybrid lines (GI56F3, J1-7, J1-9, J1-51 and J1-11). B, Southem blot containing $10 \mu \mathrm{g}$ of Eco RJ/Hind III restricted genomic DNA from various cell lines was hybridized with a $1.7 \mathrm{~kb}$ Eco RI/Hind III fragment (see Fig. 2A) under standard conditions. Lanes: 1, human control DNA; 2, G156F3 hybrid cell line (del proxllp14dist I Ip 12) (59); 3 to 6, J1 derived somatic cell hybnd lines J1-7 (lane 3), J1-9 (lane 4), J1-5I (lane 5), JI-II (lane 6) as described in Glaser et al. (47); 7, rodent control DNA.

has been observed exclusively with extracts from Ishikawa cells indicating that a tissue-specific factor binds to the TATA-box region (44). This region is in 15 out of 20 nucleotides conserved in the human gene.

\section{Chromosomal localization of the human $\mathrm{CC10}$ gene}

To determine the chromosomal localization of the human $\mathrm{CCl} 0$ gene a genomic $1.7 \mathrm{~kb}$ Eco RI-Hind III fragment spanning the transcriptional start point (see Fig. 2A) was hybridized to a human-mouse somatic cell hybrid panel (46). Scoring for the presence of the specific hybridization signal led to an initial assignment to chromosome 11 . This result was confirmed using a subregional mapping panel based on cell lines derived from a human chromosome 11 unique hybrid (47). The human CC10 gene is present in the cell lines $\mathrm{Jl}-7$ and $\mathrm{J} 1-9$ that carry complete chromosome $1 \mathrm{lq}$ but have different $11 \mathrm{p}$ deletions. In contrast, it is absent in the cell line $\mathrm{J} 1-11$, which retained 11 pter-11q11 (Fig. 5). From these data we conclude that the human $\mathrm{CCl0}$ gene is localized in the chromosomel lq11-qter region.

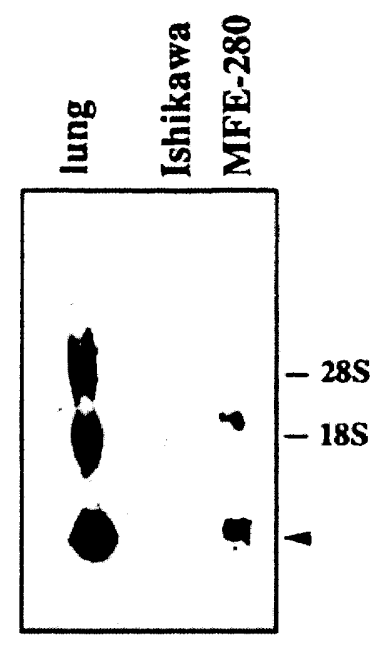

Figure 6. Human CC10 mRNA expression. Northern blot analysis: Total RNA from tung $(4 \mu \mathrm{g})$ and poly $\left(\mathrm{A}^{+}\right)$RNA from Ishikawa $(4 \mu \mathrm{g})$ and MFE-280 cells $(4 \mu \mathrm{g})$ were electrophoresed through $1.5 \%$ agarose, bloted to a nylon membrane and hybridized to 32P-labelled human uteroglobin cDNA. The positions of the $28 S$ and 185 markers are indicated. The arrow depicts the uteroglobin mRNA signal.

Human CC10 is expressed in a cell line of endometrial origin Human CC10 was originally isolated from lung Clara cells and therefore designated $10 \mathrm{kDa}$ Clara cell secretory protein. In addition to this bronchiolar cell type, rabbit uteroglobin is expressed in certain epithelial cells of the endometrium, oviduct, male genital tract and esophagus. When we analyzed total RNA from five different samples of human endometrial tissue, we could not detect any CC10 mRNA (data not shown). In contrast, human CC10 mRNA is detectable in the cell line MFE-280 (Fig. 6) that has been recently established from a human adenocarcinoma of endometrial origin (to be published elsewhere). Furthermore, by Northern blot analysis human CC10 mRNA is not detectable in another cell line, the Ishikawa cell line (48). The amount of CCIO mRNA in MFE- 280 cells is very low compared to the lung. The signal we obtain with $4 \mu \mathrm{g}$ total lung RNA is approximately 4 -fold stronger compared to the signal obtained with $4 \mu \mathrm{g}$ of poly $(\mathrm{A})^{+}$ RNA from the MFE-280 cell line. As only $4 \%$ of all lung cells (the Clara cells lining the bronchiolar epithelium) express $\mathrm{CC} 10$ (49) we estimate that the amount of human CC10 mRNA per cell in the MFE-280 cell line is approximately 1,000-fold lower than in lung Clara cells in vivo. Rabbit uteroglobin mRNA expression in rabbit endometrium is strongly inducible by sequential treatment with estrogen and progesterone. As the MFE-280 cell line does not contain significant amounts of the corresponding steroid hormone receptors (unpublished results) we could not analyze the hormonal inducibility of the human CC10 mRNA in this cell line.

\section{DISCUSSION}

A human cDNA clone coding for a 91 amino acid protein that shows $61 \%$ identity to rabbit uteroglobin on the protein level has been previously isolated and designated as $10 \mathrm{kDa}$ Clara cell secretory protein (CC10) according to its expression in lung Clara 
cells (8) or as $17 \mathrm{kDa}$ Clara cell secretory protein which indicates the correct molecular weight (1). Further structural and functional features of the protein suggest that it is the human homologue of rabbit uteroglobin. Nevertheless, it was argued that CC10 may not be uteroglobin (5). To clarify this point, the amount of divergence at synonymous (silent) and nonsynonymous sites between human $\mathrm{CCl}$, rat $\mathrm{CCl} 10$ and rabbit uteroglobin coding regions was analyzed. Our data show that human $\mathrm{CC} 10$ and rabbit uteroglobin are more closely related to each other than to rat $\mathrm{CC10}$, thus providing good evidence for a one gene hypothesis. The finding that the average numbers of substitutions per site for the uteroglobin/CC10 gene are higher than for many other genes shows that it is evolving at higher speed than average. Most likely this is a consequence of only moderate constraints by the function(s) of the protein on its primary structure. Moreover, Southern blot analysis indicates that there exists only a single $\mathrm{CCl} 10$ gene in man $((8)$ and our own unpublished results). Therefore, to circumvent different misleading nomenclatures we propose to designate the human as well as the rat homologues $(6,7)$ of rabbit uteroglobin as uteroglobins according to the designation in the species where it was first described.

Human uteroglobin/CC10 mRNA is strongly expressed in lung Clara cells. In addition, by Northern blotting the mRNA is detectable in a cell line (MFE-280) that has been established from a human endometrium carcinoma. This is the first report of endometrial cells that express endogenous uteroglobin/CC10 mRNA indicating that human uteroglobin/CClO is expressed in endometrium as is its rabbit homologue. Thus, it appears that human uteroglobin/CC10 is not only a marker for lung Clara cells but also an endometrial differentiation marker. Human uteroglobin/CCIO $\mathrm{cDNA}$ or antibodies to the protein may be used to characterize endometrium derived tumors. Several reasons might account for the finding that human uteroglobin/ $\mathrm{CCl} 0$ mRNA is expressed in an endometrium-derived cell line but has not been detectable in a series of normal tissue samples from uterus. As rabbit and murine uteroglobin/CC10 are expressed exclusively in the luminal and the glandular epithelium $(5,28)$ it is likely that human uteroglobin/CC10 mRNA expression is also restricted to these epithelial layers. We have extracted and analyzed total RNA from whole organs and, therefore, it is possible that we have been below the detection level. Alternatively, human uteroglobin/CC10 mRNA might not be expressed constitutively in the uterus during the menstrual cycle but regulated by steroid hormones similarly to rabbit (23) or rat (7) and mouse (35) uteroglobin/ $\mathrm{CC} 10$. Thus, it is conceivable that uteroglobin/CC10 expression in the uterus is restricted to a very short time period of the cycle. Some evidence for such a cycle-dependent expression comes from a previous report. A human protein cross-reactive to a monospecific anti-rabbit uteroglobin antiserum has been detected in some uterine washings obtained from women during the early and midluteal phases of the ovarian-menstrual cycle, but not in uterine washings from other menstrual phases (50).

Experiments addressing the regulation of human uteroglobin/CC10 mRNA expression in endometrium and lung by steroid hormones could not be performed as the endometrium derived cell line MFE-280 does not contain measurable amounts of steroid hormone receptors and appropriate human uteroglobinexpressing lung cell lines are not available yet. Thus, it remains unclear whether human uteroglobin/CC10 mRNA expression can be modulated by steroid hormones as described for the rabbit tissues. In this species, uteroglobin mRNA expression in endometrium can be induced by sequential treatment of estrogen and progesterone (23) and in lung glucocorticoids increase the amount of uteroglobin mRNA specifically. Sequence alignments of the human with the rabbit uteroglobin 5 '-flanking regions do not point to a similar regulation by steroid hormones. The well defined estrogen responsive element found in the rabbit uteroglobin promoter at position $-263 /-252$ (33) is not conserved in the human gene despite the overall homology in the promoter region. The cluster of progesterone receptor binding sites found in the rabbit uteroglobin 5 -flanking gene region is only partially conserved in the human gene. Close inspection of the sequence reveals that only two weak binding sites are partially conserved (32). It remains to be established whether these two partially conserved elements can still bind the progesterone receptor and can function as progesterone responsive elements. In the rat 5'-flanking uteroglobin gene region the hormone receptor binding sites described for the rabbit gene are also absent. Nevertheless, expression of uteroglobin/CCl0 mRNA in rat uterus is inducible with estrogen/progesterone (7) and in lung cortisol modulates uteroglobin mRNA expression (7). Therefore, the absence of the discussed steroid hormone receptor binding sites in the human 5 '-flanking gene region does not necessarily indicate that expression of the gene is not regulated by steroid hormones. Still unidentified hormone responsive elements or an indirect effect of the hormones may account for these observations. A computer search for potential glucocorticoid/progesterone receptor binding sites revealed five half palindromic recognition sites (TGTYCT) located at positions $-2509 /-2504,-2382 /-2387,-1018 /-1023,-804 /-809$ and $-777 /-782$.

Comparison of the human uteroglobin/ $\mathrm{CC} 10$ promoter to the rabbit uteroglobin promoter reveals that elements from -258 to $-220 \mathrm{bp}$ and from -205 to -177 bp that are very important for the transient activity of the rabbit promoter in Ishikawa cells (44) are not conserved in the human promoter. In contrast, the sequence further downstream from -180 bp to the TATA box is well conserved between human and rabbit. In that region at least 4 distinct footprints have been observed in DNasel protection experiments (44). The significance of these and other cis-elements for the cell type-specific expression of the uteroglobin genes remains to be elucidated in gene transfer experiments. In vitro transcription experiments with Ishikawa cell nuclear extracts have already shown that the region between -96 and -35 bp is important for the activity of the rabbit promoter. To further narrow down the relevance of the promoter sequence that is conserved between the rabbit and human uteroglobin/ $\mathrm{CCl} 10$ genes we have generated linker scanning mutations in the appropriate promoter region and are currently investigating these mutants in gene transfer experiments. For these kind of experiments the MFE-280 cell line will be very useful.

\section{MATERIALS AND METHODS}

\section{Cell culture}

Ishikawa cells were cultured as described previcusly (33). MFE-280 cells were denved from a recurrent endometrium carcinoma. The fumor was placed at the pelvic wall and classified as a poorly differentiated adenccarcinoma. The cells were grown in suspension in DMEM medium, supplemented with 10\% FCS, $40 \mathrm{IU} / \mathrm{insulin,} 2.5 \mathrm{mg} / \mathrm{transferrin,} 10 \mathrm{nM} 17 \beta$-estradiol and $67 \mu \mathrm{g} / \mathrm{ml}$ gentamycune sulfate. 
Northern blot analysis

Total RNA from human lung and cell lines was extracted by the guanidunium/phenol procecture (51). Poly $\left(\mathrm{A}^{+}\right)$RNA was isolated by oligo (dT) cellulose chromatography using the QuickPrep mRNA Purification Kit from Pharmacia. Total and poly $\left(\mathrm{A}^{+}\right)$RNA were separated on $1.5 \%$ agarose gels containing $2.2 \mathrm{M}$ deionized formaldehyde and blotted to nylon membranes (Pall Biodyne B). Prehybndization and hybridizauon was carried out as described (7) using ${ }^{32 \mathrm{P}}$ labelled human $\mathrm{CC} 10 \mathrm{CDNA}(8)$ as prabe. The specific activity of the probe was approximately $5 \times 10^{8} \mathrm{cpm} / \mu \mathrm{g}$.

\section{S1 nuclease mapping}

SI nuclease mapping was carried oul as described (52,53). A 639 bp EcoRI-Pstl fragment from plasmid clone phUGprom (see 'Gene isolation and mapping' and Fig. 2A) was dephosphorylated and end-labelled with T4 polynucleotide kinase and $\left[\gamma^{32}\right.$ P]ATP according to standand procedures (54). After digestion with Sacl, the resulung 283 bp Pst-Sacl fragment spanning the presumed transcriptional start site was isolated and hybndized to total RNA from human lung and Ishikawa cells, respectively. Hybridization was performed with $10,000 \mathrm{cpm}$ and $10 \mu \mathrm{g}$ total RNA in $40 \mathrm{mM}$ Pipes, pH 6.5, $0.4 \mathrm{M} \mathrm{NaCl}, 1 \mathrm{mM}$ EDTA, $80 \%$ formamude at $42^{\circ} \mathrm{C}$ overnight. After 5 -fold dilution with $30 \mathrm{mM}$ sodium acetate, $3 \mathrm{mM}$ zinc acetate, $S 1$ nuclease digestions were carried out at $30^{\circ} \mathrm{C}$ for $45 \mathrm{~min}$ with various S1 nuclease concentrations as indicated in the legend to Fig. 2B. The reaction was stopped with $15 \mathrm{mM}$ EDTA, phenol extracted and ethanol precipitated prior to electrophoresis

\section{Southern blot analysis}

High-molecular-mass DNA was isolated and purified from hybrid cell lines according to standard procedures (54). The DNA $(10 \mu \mathrm{g})$ was digested with Eco $\mathrm{RL} / \mathrm{Hind} \mathrm{m}$ and separated on $0.8 \%$ agarose gels. After bloting to nylon membranes prehybridization and hybridization were carned out as described for the Northern blot analysis.

\section{Gene bolation and mapping}

A commercully available human genomic $\lambda$ fix phage library (Stratagene) prepared from the human lung fibroblast cell line $W_{1} 38$ was screened with human $\mathrm{CC}_{10}$ cDNA (8). One positive clone was identified. After three rounds of rescreening, bacteriophage DNA was prepared from single plaques according to Grossberger (55). A partial restriction map was obtained by single and double digestions with Bam HI, Eco RI and Hind III, separation through 0.8\% agarose and Southern blot analysis (54) using subfragments of the human CC10 CDNA as probes. To facilitate further mapping and sequence analysis of the promoter region a 44 kb Bam HI-Hind III fragment that hybridized exclusively to a 60 bp Eco RI-Pst I human $\mathrm{CC} 10 \mathrm{cDNA}$ subfragment containing the codons for the 16 most $\mathrm{NH}_{2}$-terminal amino acids (8) was subcloned into the plasmid vector pSPT 19 (phUGprom).

\section{DNA sequencing}

The dideoxy chain termination method (54) was employed for sequence determination using the Pharmacia T7 secquencing kit and [ $\alpha^{35}$ S] dATP (specific activity: $22 \mathrm{TBq} / \mathrm{mmol}$ ) throughout. Plasmids were denarured with alkals and hybndized to chemically synthesized 17 to 26-mer oligonucleotide primers for plasmid and insert-specific sequences. For low level analysis of sequences the computer program DNA Strider I.I (56) was used.

\section{ACKNOWLEDGEMENTS}

Dr M.Kalfi-Suske is gratefully acknowledged for critical reading of the manuscript. We thank Dr. P.Sharp for discussions and providing the computer program LWL90 writen by Dr. K.H.Wolfe. Drs. S.L.Katyal and G.Singh kindly provided the human $\mathrm{CClO} / \mathrm{uteroglobin} \mathrm{CDNA}$. This work was supported by a grant from the Deutsche Forschungsgemeinschafi (Mu601/5-1) and by the Fonds der chemischen Industrie.

\section{REFERENCES}

I. Umland, T.C., Swaminathan,S., Furey,W., Singh,G., Pletcher, J. and Sax,M (1992) J. Mol. Biol. 224, $441-448$.

2 Singh, G. and Katyal,S.L. (1984) J. Histochem. Cyrochem. 32, 49-54.

3. Singh,G., Singal.S., Katyal,S.L., Brown,W.E. and Gottron,S.A. (1987) Eq. Lung Res. 13, 299-309.
4. Nordlund-Möller,L., Andersson,O., Ahlgren,R., Schilling,J., Gillner,M., Gustafsson,J.-A. and Lund,J. (1990) J. Biol. Chem. 265, 12690-12693.

5. Singh,G., Katyal,S.L., Brown, W.E., Kennedy, A.L., Singh, U. and WongChong,M.-L. (1990) Blochim. Biophys. Acta, 1039, 348-355.

6. Katyal,S.L., Singh,G., Brown,W.E., Kennedy,A.L., Squeglia, N. and Wong Chong,M.-L. (1990) Prog. Respir. Res.. 25, 29-35.

7. Hagen,G., Wolf,M., Katyal,S.L., Singh,G., Beato,M. and Suske,G.(1990) Nucleic Acids Res. 18, 2939-2946.

8. Singh,G., Katyal,S.L., Brown,W.E., Phillips,S , Kennedy, A.L., Anthony,J. and Squeglia, N.(1988) Biachim. Biophys. Acta 950, 329-337.

9. Morize,I., Surcouf,E., Vaney,M.C., Epelboin,Y., Buehner, M., Fridlansky,F., Milgrom,E. and Momon,J.P. (1987) J. Mol. Biol. 194, 725-739.

10. Berer,H.M. (1968) Biochem. Biophys. Acra. 160, 289-291.

11. Kurchner,C. (1976) Cell Tissue Res. 170, 490-492.

12. Beier,H.M., Bohn,M and Müler,W. (1975) Cell Tissue Res. 165, 1-11.

13. Noske,I.G. and Feigelson, M. (1976) Biol. Reprod., 15, 704-713.

14. Torkkeli, T., Krusius, T. and Jänxe,O (1978) Biochem. Biophys. Acta, 544, $578-592$.

15. Beato,M. and Baier,R. (1975) Biochim. Biophys. Acto 392, 346-356.

16. Beato,M., Amemann,J. and Voss,H.J. (1977) J. Sieroid Biochem. B, $725-730$.

17. Atger,M. Savouret,J.F. and Milgrom,E. (1980) J. Steroid Biachem. 13, $1157-1162$.

18. Gillner,M., Lund,J., Cambillau,C., Alexandersson,M., Hurtig,U., Bergman,A., Klasson-Wehler,E. and Gustafsson,J.A. (1988) J. Steroid Biachem. 31, 27-33.

19. Lund,J., Brandt,I., Poellinger,L., Bergman,A., Klasson-Wehler,E. and Gustafsson,J.A. (I985) Mol. Pharmacol. 27, 314-323.

20. Levin, S.W., Butler,J.D., Schumacher, U.K., Wightman,P.D. and Mukheree, A.B. (1986) Life Sci. 38, 1813-1819.

21. Miele,L., Condella-Miele,E. and Mukherjoc,A.B. (1987) Endocr. Rev. 8, $474-490$.

22. Miele,L , Cordella-Miele,E., Facchiano,A. and Mukherjee,A.B. (1988) Nature 335, 726-730.

23. Beato,M., Arnemann,J., Menne,C., Müller,H., Suske,G. and Wenz,M. (1983) in McKerns, K.W. (ed.), Regulation of Gene Expression by Hormones. Plenum Press, New York, pp. $151-175$.

24. Muller,H. and Beato,M. (1980) Eur. J. Biochem., 112, 235-24I.

25. Lopez de Haro,M.S., Alvarez, L. and Nieto,A. (1988) Biochem. J. 250. $647-651$.

26. Femandez-Renau,D., Lombardero,M. and Nieto,A. (1984) Eur. J. Biochem. 144, 523-527.

27. Lopez de Haro,M.S. and Nieto,A. (1985) Brochem. J. 225, 255-258.

28. Warembourg,M., Tranchant, O., Atger,M. and Milgrom,E. (1986) Endocrinology 119, 1632.

29. Menne,C., Suske,G., Amemann,J., Wenz,M., Cato,A.C.B. and Beato,M. (1982) Proc. Nall. Acad. Sci. USA, 79. 4853-4857.

30. Suske,G., Wenz,M., Cato,A.C.B. and Beato,M. (1983) Nucleic Acids Res. 11, 2257-2271.

31. Cato,A.C.B., Geisse,S., Wenz,M., Westphal,H.M. and Beato,M. (1984) EMBO J. 3, 2771-2778.

32. Jantzen,K., Frition,H.P., Igo-Kemenes, T., Espel,E., Janich,S., Cato,A.C.B., Mugele, $K$ and Beato,M. (1987) Nucleic Acids Res. 15, 4535-4552.

33. Slater,E.P., Redeuihl,G., Theis,K., Suske,G. and Beato,M. (1990) Mol. Endocrinol. 4, 604-610.

34. Nieto,A. and Lombandero,M. (1982) Comp. Biachem. Physiol. B 71 , $511-514$.

35. Sandmoller,A., Voss,A.K., Hahn,J., Redemann-Fibi,B., Suske,G. and Beato,M. (1991) Mechanisms of Developmen 34, 57-68.

36. Lopez de Haro,S. and Nieto, A. (1986) Biochem. J. 235, 895-898.

37. Li,W.-H., Tanimura,M., Luo,C.-C., Datta,S. and Chan, L. (1988) J. Lipid Res. 29, 245-271.

38 Li,W.-H., Gouty,M., Sharp,P.M., O'hUigin,C. and Yang, Y.-W. (1990) Prac. Nall. Acad. Sci. USA 87, 6703-6707.

39. Bulmer,M., Wolfe,K.H. and Sharp,P.M. (1991) Proc. Nath Acad. Sci. USA 88, $5974-5978$.

40. Sollner-Webb,B. and Reeder, R.H. (1979) Cell 18, 485-499.

41. Devereux,J., Haeberli,P. and Smithies,O. (1984) Nucleic Acids Res. 12 $387-395$.

42. Schmid,C.W. and Jelinek,W.R. (1982) Science, 216, 1065-1070.

43. Ullu,E. and Tschudi,C. (1984) Nature, 312, 171-172.

44. Misseyanni,A., Klug,J., Suske,G. and Beato,M. (1991) Nucleic Acids Res. 19. $2849-2859$. 
378 Human Molecular Genetics, Vol. 1, No. 6

45. Rosenfeld,M.G. (1991) Genes \& Dev. 5, 897-907.

46. Willecke,K., Jungbluth,S., Dahl,E., Hennemann,H., Heynkes, R. and Grzeschuk,K.H. (1990) Eur. J. Cell Biol. 53, 275-280.

47. Glaser, T., Housman, D.E., Lewis, W.H., Gerhand,D. and Jones, C. (1989) Somatic Cell Mol. Genesics 15, 477-501.

48. Nishida,M., Kasahass, K., Kaneko,M. and Iwasaki,H. (1985) Acra Obstet.Gynaec. Jap. 37, 1103-1111.

49. Singh,G., Singh,J., Katyal,S.L., Brown,W.E., Kramps,J.A., Paradis,J.L., Dauber,J.H., Macpherson,T.A. and Squeglia,N. (1988) J. Histochem. Cyrochem, 36, 73-80.

50. Cowan,B.D., North,D.H., Whitworth,N.S., Fujita,R., Schumacher,U.K. and Mulherjee,A.B. (1986) Fertil. Sieril. 45, 820-823.

51. Chomczynski,P. and Sacchi,N. (1987) Anal. Biochem. 162, 156-159.

52. Berk,A.J., and Sharp,P.A. (1977) Cell 12, $721-732$.

S3. Weaver, R.F. and Weissmann,C. (1979) Nucleic Acids Res. 7, 1175- 1193.

54. Maniatis, T., Fritsch,E.F., Sambrook, J. (1982) Molecular Cloning: A Laboratory Manual. Cold Spring Harbor.

55. Grossberger,D. (1987) Nucleic Acids Res. 15, 6737.

56. Marck, C. (1988) Nucleic Acids Res. 16, 1829-1836.

57. Li,W.-H., Wu,C.-I, and Luo.C.C. (1985) Mol. Biol. Evol. 2, 150-174.

58. Higgins,D.G. and Sharp.P.M. (1988) Gene 73, 237-244.

59. Gessler,M., Thomas,G.H., Coullin,P., Junien,C., McGillivray,B.C., Hayden,M., Jaschek,G. and Bruns,G.A.P. (1989) Amer. J. Hum. Genet. 44, 486-495. 